\title{
Municipal solid waste characterization and it is assessment for potential compost production: A case study in Zanjan city, Iran
}

\author{
Habib Fathi ${ }^{1}$, Abdolhossinpari Zangane ${ }^{2}$, Hamed Fathi ${ }^{3,}$, , hossein moradi ${ }^{4}$ \\ ${ }^{1}$ Academic center for Education, Culture and Research, Environmental Research Instituterasht, Iran \\ ${ }^{2}$ Zanjan University Department of chemistry Zanjan, Iran \\ ${ }^{3}$ Department of soil Sciences, college of Agriculture, Gorgan University of agriculture sciences and Natural resources Gorgan, Iran \\ ${ }^{4}$ Higher educational complex of saravan, Iran
}

\section{Email address:}

hamed_fathi_dokht@yahoo.com (H. Fathi)

\section{To cite this article:}

Habib Fathi, Abdolhossinpari Zangane, Hamed Fathi, hossein moradi. Municipal Solid Waste Characterization and It Is Assessment for Potential Compost Production: A Case Study in Zanjan City, Iran. American Journal of Agriculture and Forestry.

Vol. 2, No. 2, 2014, pp. 39-44. doi: 10.11648/j.ajaf.20140202.14

\begin{abstract}
The increasing amount of municipal solid waste (MSW) generations and their improper disposal have great social costs, and is an issue of increasing concern. There are strict mandatory targets in many nations to reduce the amount of MSW entering the landfill. At present, the source reducing, recycling, reusing, waste combusting, and also composting the MSW are the major strategies which are being advised spread across the world. Municipal solid waste management (MSWM) practices in Zanjan, a city with population of about 350,000 persons, are generating about 300 tons of MSW daily those are consisting of the collection, transportation and land filling of the wastes. The wastes are not recycled and composted but just mainly land filled. Therefore, this research is conducted to study the generation, characterization and management strategies of solid wastes in Zanjan city. The samplings of MSW were performed in all four seasons during 2010 and the contents of its main components are determined. The qualitative and quantitative results indicated that the composting of MSW is feasible and can be adopted as a proper MSWM approach in the studied area. Recycling of paper, plastic and glass along with composting of MSW are highly recommended.
\end{abstract}

Keywords: Municipal Solid Waste Management, Composting, Recycling, Zanjan, Solid Waste

\section{Introduction}

Solid waste is a serious environmental problem in both developing and developed nations. Most developing countries have recently started to improve their municipal solid waste management practices. Inadequate management of solid waste leads to problems that impair human and animal health and ultimately result in economic, environmental and biological losses (Sharholy et al., 2008). In these countries MSW is generally disposed of in lowlying areas without taking any precautions or operational controls. Therefore, MSWM is one of the major environmental problems confronting many developing countries. MSWM involves activities associated with waste generation, its storage, collection, transfer and transport, processing and disposal. In most Iranian cities, the MSWM system comprises only for four activities, i.e., waste generation, collection, transportation, and disposal (Ziaee et al., 2012). The management of MSW requires proper infrastructure, maintenance and upgrade for all activities. This is very expensive and complex due to the continuous and unplanned growth of urban centers. Providing the desired level of public service in the urban centers is often attributed to the poor financial status of the managing municipal corporations (Ahsan., 1999, Mor., 2006, Raje et al., 2001, Siddiqui et al., 2006, Kumar Kaushal et al., 2012). Per capita generation and characteristics of household waste depends on household income levels and area characteristics. MSW generation in Asia in 1998 was 0.76 million ton/day (Jin et al., 2006) with a growth rate of 2-3 percent annually in developing countries as compared to 3.2 - 4.5 percent in developed countries. The per capita MSW generation rate is varied in different parts of Asia ranging from $0.88 \mathrm{~kg} /$ day in Iran (Damghani et al., 2008) to $0.95 \mathrm{~kg} /$ day in Turkey (Metin et al., 2003) and $1.21 \mathrm{~kg} /$ day 
in China (El-Salam, M. M. A. 2013).

The MSW disposal problems can be reduced by waste minimization, reuse and recycling of its components and converting the organic components of the waste into a valuable product and reused without adversely affecting the environment. This can be achieved by converting the waste into biogas through anaerobic digestion and into plant nutrients by way of composting (Mbuligwe and Kassenga2004, Jha 1 et al., 2013). Compost characteristics are essentially dependent upon the raw materials and the factors that affect the progress of the process. The factors affecting the composting process can be divided into two groups: those depending on the formulation of the composting mix, such as nutrient balance, $\mathrm{pH}$, particle size, porosity and moisture; and those dependent on the process management, such as $\mathrm{O}_{2}$ concentration, temperature and water content. Nutritional balance is mainly defined by the Carbon/Nitrogen ratio. Microorganisms require an energy source (degradable organic Carbon) and Nitrogen for their development and activity (Hubbeet al., 2010).

This study was conducted in ZanjanProvince which occupies about $1.3 \%$ of Iranian territory and has an area of 22,164 square kilometers. The province is located in the northwestern part of Iran between latitudes $36^{\circ} 27^{\prime}$ and $37^{\circ}$ $15^{\prime} \mathrm{N}$ and longitudes $47^{\circ} 17^{\prime}$ and $48^{\circ} 54^{\prime}$ E. Zanjan Province has a population of nearly $1,077,254$ people which is about $1.5 \%$ of Iran's population. Zanjan city is the capital of the province with a population of about 350,000 people. The municipality of Zanjan is responsible for all aspects of solid waste management. Zanjan has a main municipality and is composed of 3 sub municipalities. MSWM practices in Zanjan, generating about 300 tons of MSW daily, consist of collection of waste, waste transportation and land filling. The waste is mainly land filled and recycling and composting are not yet introduced. This paper presents an overview of current MSWM system in Zanjan city, and provides several recommendations for its improvements.

\section{Materials and Methods}

To perform household wastes management studies in any city, it is necessary to know the constituents of wastes; that is physical and chemical analysis, measurement of weight, volume, quality and quantity of wastes produced in different seasons. Hence in this method, based on the most recent instructions available, the wastes from different localities of Zanjan city were collected during seven continues days in the mid of each seasons during 2010. After analysis and evaluation of MSW, the results were used in studying the quality of wastes from Zanjan City.

\subsection{Sample Collection and Segregation}

MSW samples were collected through seven working days in each season and from each of four different communities (i.e. High class districts, Middle economic class, Low class and commercial districts).This means a total number of 20 samples were collected and segregated per day from four different socioeconomic localities. The samples were then segregated manually into different physical components such as; organic material, paper, plastics, rubber, wood, glass, metals, textiles and PET. Each of these recyclable materials was weighted to determine its fraction in the total solid waste sample collected. The remaining material was a uniform mixture of soil, mud, sand and other inert materials that were not manually separable, and is termed mixed organic materials. $1.5 \mathrm{~kg}$ of this mix from each sample was collected in polyethylene bags, brought to the laboratory, and analyzed for moisture content immediately. The remaining samples were stored and analyzed for other important parameters.

\subsection{Laboratory Sample Analyses}

Representative samples (organic components) were first grounded to homogenous powder in a miller apparatus and then the following analyses were carried out.

Moisture content: Samples of $100 \mathrm{~g}$ were taken in triplicate, dried to a constant weight in an oven at $105^{\circ} \mathrm{C}$ for $24 \mathrm{~h}$, cooled in a desiccators and the difference in weight was recorded (Vesilind et al., 2003). Moisture content was calculated using Eq. (1)

$$
\mathrm{M}_{\mathrm{n}}=\left(\left(\mathrm{W}_{\mathrm{w}}-\mathrm{W}_{\mathrm{d}}\right) / \mathrm{W}_{\mathrm{w}}\right) \times 100
$$

$\mathrm{M}_{\mathrm{n}}=$ moisture content $(\%)$ of material

$\mathrm{W}_{\mathrm{W}}=$ wet weight of the sample, and $\mathrm{W}_{\mathrm{d}}=$ weight of the sample after drying

Carbon/Nitrogen Ratio: Total Kjeldahl nitrogen and volatile solids (VS) were analyzed by standard methods (APHA, 1998). C/N ratio was calculated using Eq. (2)

$$
\frac{C}{N}=\frac{(v s \times 0.58) \% \text { drymatter }}{(\text { Kjeldhal }-N) \% \text { drymatter }}
$$

pH: $\mathrm{pH}$ of the water extract (1:5) was measured using a $\mathrm{pH}$ meter (Metrohm model 780).

Statistical sample analyses: In this paper, SPSS software (version 11.5) was used for the statistical analysis of the data.

\section{Results and Discussion}

Waste production and composition depend on many factors, such as the stage of development; socio-economic, climatic and geographical conditions; and collection frequency (Collivignarelli et al., 2004). Data on quantity variation and generation are useful in planning for a collection and disposal system (Sharholy et al., 2008).The current state of Zanjan MSW management, its challenges and our recommendations for improvement of the system are discussed in this section.

\subsection{Solid Waste Generation and Characteristics}

A comparison of the average amounts of MSW components of Zanjan city in different seasons are reported 
in Table $1 \& 2$. The amount of waste produced in Zanjan is 300 tons per day. Qualitative study of the MSW sampled in different seasons, different social areas of the city (According to the culture of consumption and waste production that is associated with life)and different economic classes shows that maximum percent of organic materials in MSW are found in low economy class in spring and minimum organic contents belongs to samples from commercial areas in autumn. On the other hand, the maximum total dry recyclable waste in MSW is from commercial regions in summer, and minimum such contents are related to the lower economic classes and in autumn. The highest dispersal is related to organic materials.

Table 1. Composition of municipal solid waste in different socioeconomic localities (high, middle, low and commercial localities).

\begin{tabular}{|c|c|c|c|c|c|c|c|c|c|c|c|c|c|}
\hline $\begin{array}{l}\text { Socio- } \\
\text { econom } \\
\text { ic } \\
\text { Localiti } \\
\text { es } \\
\end{array}$ & $\begin{array}{l}\text { organic } \\
\text { material(Perc } \\
\text { ent } \%)\end{array}$ & $\begin{array}{l}\text { paper } \\
\text { (Percent } \\
\text { \%) }\end{array}$ & $\begin{array}{l}\text { Card } \\
\text { board } \\
\text { (Percent } \\
\% \text { ) }\end{array}$ & $\begin{array}{l}\text { rubber } \\
\text { (Percent } \\
\%)\end{array}$ & $\begin{array}{l}\text { plastic } \\
\text { (Percent } \\
\% \text { ) }\end{array}$ & $\begin{array}{l}\text { PET } \\
\text { (Percent } \\
\%)\end{array}$ & $\begin{array}{l}\text { textiles } \\
\text { (Percent } \\
\% \text { ) }\end{array}$ & $\begin{array}{l}\text { glass } \\
\text { (Percent } \\
\%)\end{array}$ & $\begin{array}{l}\text { iron } \\
\text { (Percent } \\
\% \text { ) }\end{array}$ & $\begin{array}{l}\text { other } \\
\text { metal } \\
\text { (Percent } \\
\% \text { ) }\end{array}$ & $\begin{array}{l}\text { sand } \\
\text { (Percent } \\
\% \text { ) }\end{array}$ & $\begin{array}{l}\text { wood } \\
\text { (Percent } \\
\%)\end{array}$ & $\begin{array}{l}\mathrm{D}(\mathrm{kg} / \\
\left.\mathrm{m}^{3}\right)\end{array}$ \\
\hline $\begin{array}{l}\text { High } \\
\text { Class }\end{array}$ & 64.1 & 5.3 & 4.9 & 0.1 & 9.3 & 2.7 & 3.0 & 4.0 & 0.7 & 2.5 & 1.9 & 1.2 & 189 \\
\hline $\begin{array}{l}\text { Middle } \\
\text { Class }\end{array}$ & 66.1 & 3.9 & 5.3 & 0.2 & 9.1 & 2.3 & 3.5 & 5.1 & 0.6 & 1.9 & 0.8 & 1.1 & 194 \\
\hline $\begin{array}{l}\text { Low } \\
\text { Class }\end{array}$ & 67.5 & 3.7 & 4.5 & 0.9 & 7.7 & 1.9 & 2.9 & 3.1 & 0.9 & 1.8 & 2.6 & 2.2 & 275 \\
\hline $\begin{array}{l}\text { Commer } \\
\text { cial }\end{array}$ & 46.7 & 6.6 & 5.8 & 1.4 & 12.6 & 2.2 & 5.8 & 3.1 & 3.3 & 3.2 & 4.4 & 4.4 & 187 \\
\hline Mean & 61.4 & 4.8 & 5.1 & 0.7 & 9.7 & 2.2 & 3.8 & 3.0 & 1.4 & 2.3 & 2.4 & 2.2 & 210 \\
\hline
\end{tabular}

Table 2. Composition of municipal solid waste in different seasons (by percent)

\begin{tabular}{|c|c|c|c|c|c|c|c|c|c|c|c|c|c|}
\hline Seasons & $\begin{array}{l}\text { organic } \\
\text { material }\end{array}$ & paper & $\begin{array}{l}\text { Card } \\
\text { board }\end{array}$ & rubber & plastic & PET & textiles & glass & iron & $\begin{array}{l}\text { other } \\
\text { metal }\end{array}$ & sand & wood & $\mathrm{D}\left(\mathrm{kg} / \mathrm{m}^{3}\right)$ \\
\hline Autumn(October) & 57.5 & 4.4 & 4.0 & 0.0 & 9.5 & 1.5 & 6.1 & 5.3 & 2.4 & 1.7 & 3.0 & 3.5 & 160 \\
\hline Winter(January) & 62.9 & 4.9 & 5.7 & 0.7 & 11.4 & 2.1 & 2.5 & 3.1 & 0.4 & 2.6 & 2.4 & 1.2 & 206 \\
\hline Spring(April) & 63.5 & 5.3 & 5.3 & 0.8 & 9.4 & 2.4 & 3.3 & 3.2 & 1.0 & 2.5 & 2.2 & 1.9 & 201 \\
\hline Summer(July) & 61.5 & 4.7 & 5.3 & 1.4 & 8.5 & 3.0 & 3.2 & 3.7 & 1.9 & 2.5 & 2.0 & 2.2 & 276 \\
\hline Mean & 61.4 & 4.9 & 5.1 & 0.7 & 9.7 & 2.2 & 3.8 & 3.8 & 1.4 & 2.3 & 2.4 & 2.2 & 210 \\
\hline
\end{tabular}

\subsection{Waste Handling and Separation/Processing at Source}

The method of handling, storage and processing of solid wastes at the source plays an important role in public health, aesthetics and the efficiency of the MSW system (Abdoli, 1995). Source separation of wastes will not only bring economic benefits, but also make the recycling of other components more efficient (Aydin, 2004).Unfortunately, separation of household wastes is not yet considered in MSWM program in Zanjan city.

\subsection{Collection of Solid Wastes}

Collection, transportation and disposal of MSW are the critical problems of the MSWM in any city today (Kinman, 1987).The organic parts of MSW can be easily degraded, which causes problems in storage containers. In Zanjan, municipalities are fully responsible for waste collection and transportation directly, using their own infrastructure, and indirectly through private sector contracts. At present, both mechanical and manual methods are used to collect residential waste. Although mechanical methods of collection have been implemented in some parts of the city, direct lifting and carrying of waste to the collection vehicles is the most commonly used method for waste collection in most parts of Zanjancity .Almost all of the MSW generated is collected daily (including holidays) and are transported to Temporary Transfer Station (TTS) or disposal site.

\subsection{Transport and Transfer}

In recent years, the use of small TTS in different cities of Iran has become popular (Moghadam 2009) .At present, there is only one TTS in Zanjan city. The main reason for using a transfer stations is to decrease transport costs. The type of the transfer station in Zanjan is direct load. The waste that is collected by small vehicles is discharged into an open top trailer.

\subsection{Final Disposal}

Safe and reliable long-term disposal of waste is an important component of integrated solid waste management.Land filling, incineration and composting are three main methods of MSW disposal in the world.In Iran, land filling, open dumping and composting are the main methods of waste disposal (Moghadam 2009). In Zanjan, only open dumping method for waste disposal is adopted.

\subsection{Evaluation of Composting by MunicipalSolid Waste in Zanjan}

Composting is generally defined as the biological oxidative decomposition of organic constituents in wastes of almost any nature under controlled conditions. Since composting is a biological process of decomposing organic materials, it requires special conditions, particularly of 
temperature, moisture, aeration, $\mathrm{pH}$, particle size and $\mathrm{C} / \mathrm{N}$ ratio, related to optimum biological activity in the various stages of the process. The main products of aerobic composting are carbon dioxide, water, mineral ions and stabilized organic matter, often called humus. The process is accomplished through different phases(Sharma et al., 1997).

Amount of biodegradable materials in MSW of Zanjan is 75.2 percent, which comes to 225.6 tons per day and composting can be produced by utilizing almost 60 percent of MSW transferred to landfill.

The chemical composition of the bulk material affects some parameters, especially the $\mathrm{C} / \mathrm{N}$ ratio. Very high $\mathrm{C} / \mathrm{N}$ ratios delay the microbial metabolism, whereas low values cause the loss of nitrogen through ammonia volatilization (Sharma et al., 1997). Residual carbon to nitrogen ratio of Zanjan ranges between 14.22 to 19.53 and the average is 17.6. That is, its value is much lower than standards (Table 3). To obtain a high quality compost, the $\mathrm{C} / \mathrm{N}$ ratio of the waste can be adjusted to an optimum level by adding cow manure, poultry manure, garden waste etc(Jilani 2007). Another parameter of significant importance is the percentage of water content in the feed material. It is to be noted that the higher water content may cause problems for the complete oxygenation of the material, whereas the lower values, on the other hand, may interrupt the process prematurely (Sharma et al., 1997).Relative Humidity interval in MSW of Zanjan city is 67.94 to 70.3 with a mean of 69.2. The standard rates of more than 50 were identified by Zucconin\&deBestoldi (1987) as shown in table 3 . As the mean relative humidity of MSW in Zanjan is high, it has to be reduced by aeration during the process of composting.

The parameters, such as $\mathrm{pH}$, alkalinity and volatile acids, are closely inter-related in the composting process. In the beginning of the process, the formation of carbon dioxide and organic acids causes values of approximately 5-6, whereas, as the process progresses, the $\mathrm{pH}$ value reach even up to 8-8.5. This is mainly due to the decomposition of proteins, as well as elimination of the carbon dioxide (Sharma et al., 1997).

A pH of 6.7-9.0 supports good microbial activity during composting. Optimum values are between 5.5 and 8.0 (Bertoldi et al., 1983 and Miller., 1992). Usually pH is not a key factor for composting since most materials are within this $\mathrm{pH}$ range. However, this factor is very relevant for controlling N-losses by ammonia volatilization, which can be particularly high at $\mathrm{pH}>7.5$. Elemental sulphur (S) has been used as an amendment for avoiding excessively high $\mathrm{pH}$ values during composting (Mari et al., 2005). Average $\mathrm{pH}$ in four different seasons was 5.45, which is almost close to the standards (Table 3).

Concerning biological aspects, it is necessary that the starting material is qualified physically, chemically and biologically. For example, the size and consistency of particles should be such that they confer suitable porosity to the bulking material, avoiding exaggerated packing and, thus, allowing free air passage, even in a wasting pile of nearly $2 \mathrm{~m}$ height. In order to avoid any eventual slowing of the microbiological degradation, the particle size must be in the $\mathrm{cm}$ range because the microbial transformation of a substance is directly proportional to the surface area available (Sharma et al., 1997). Most organic materials in MSW of Zanjan are in range of $8-40 \mathrm{~mm}$ (Table 4). Therefore in production of compost it is necessary to mill the organic components to have a more homogenous mater.

Table 3. Average chemical composition of MSW in Zanjan and the standard values Suitable for composting

\begin{tabular}{llllll}
\hline MSWComponents & Autumn & Winter & Spring & Summer & $\begin{array}{c}\text { Mean } \\
\text { suitable forcomposting }\end{array}$ \\
\hline $\begin{array}{l}\text { Organic matter } \\
\text { (\% wet basis) }\end{array}$ & 57.53 & 62.95 & 63.54 & 61.53 & 61.38 \\
C & 44.50 & 38.46 & 37.90 & 55.35 & 44.05 \\
N & 3.20 & 2.30 & 2.01 & 2.94 & 2.61 \\
C/N & 14.23 & 17.96 & 19.53 & 18.91 & 17.66 \\
pH & 5.25 & 5.49 & 5.515 & 5.55 & $25-50: 1$ \\
Moisture & 67.94 & 70.30 & 69.28 & 69.33 & 5.45 \\
\hline
\end{tabular}

* Standard (Zucconin\&deBertoldi, 1987)

Table 4. Composition of particle size in MSW

\begin{tabular}{llllll}
\hline Particle size(mm) & Autumn & Winter & Spring & Summer \\
\hline $8>$ & 10.42 & 10.84 & 10.26 & 10.85 & Mean \\
$8-120$ & 51.22 & 50.67 & 49.47 & 49.22 & 592 \\
$40-120$ & 33.70 & 32.14 & 33.80 & 34.27 & 5.147 \\
$120<$ & 4.62 & 6.32 & 4.48 & 33.477 & 5.53 \\
\hline
\end{tabular}

\subsection{Seasonal Change in MSW Characteristics}

ANOVAs test was used to differentiate organic material contents and $\mathrm{C} / \mathrm{N}$ ratio in samples collected in four different seasons with three degrees of freedom, mean squares of respectively 51.3 and 39.5 in the $5 \%$ significance level test (0.014 and 0.04$)$ are significant.
Relative humidity also with three degrees of freedom, mean squares of 6.6 , and significant level of $5 \%$ is not significant.

\section{Conclusion}

The waste analysis of Zanjan showed that the percentage of organic waste in the MSW is substantially high, mainly 
due to the use of unprocessed food in the daily diet of inhabitants. At present, both mechanical and manual methods are used for the collection of residential wastes. Due to high organic components and its high moisture content, the MSW must be collected daily and transferred to disposal site, substantially increasing the cost of solid waste management.

Composting of MSW are feasible in the studied area and compost production can be chosen as a proper management methodutilizingabout60 percent of MSW generated, and substantially reducing the amount of waste land filled .Since composting is a biological process of decomposing organic materials, it requires special conditions, particularly of temperature, moisture, aeration, $\mathrm{pH}$, particle size and $\mathrm{C} / \mathrm{N}$ ratio. 61.38 percent of the total MSW produced in Zanjan (184.2 tons per day) is biodegradable and can be used for compost production. Average $\mathrm{C} / \mathrm{N}$ ratio of the MSW was low (17.6) and must be adjusted to an optimum level by adding cow or poultry manure. Average $\mathrm{pH}$ values of MSW were 5.4 which are almost close to optimum values for composting. Mean relative humidity was high $(69.2 \%)$ and may be reduced by aeration during the process of composting. In order to avoid any eventual slowing of the microbiological degradation during the process of composting, it is necessary to mill the organic components to have a more homogenous mater. Recycling of paper, plastic and glass along with composting of MSW are also advised.

\section{Acknowledgment}

Department of Environment in Zanjan province is acknowledged for their financial and scientific collaboration.

\section{References}

[1] Abbasi FM, Ahmad H, Perveen F, Inamullah, Sajid M, Brar DS 2010.Assesment of genomic relationship between Oryza sativa andOryzaaustraliensis. Afr. J. Biotechnol. 9(12): 1312-1316.

[2] Abdoli MA, 1995. Solid waste management in Tehran. Waste Management and Research. 13: 519-531.

[3] Ahsan N, 1999. Solid waste management plan for Indian megacities.Environmental Protection. 19 (2): 90-95.

[4] APHA (American Public Health Association), AWWA (American Water Works Association), and WEF (Water Environmental Federation), Standard Methods for the Examination of Water and Waste Water, $20^{\text {th }} \mathrm{Ed}$, APHA, Washington DC, 1998.

[5] Aydin GA, and Kocasoy G, 2004.Significance of Source Separation and Composting of Wastes of Istanbul: From Theory To Practice. Paper Presented at the ISWA World Congress. Rome. October 17-21.

[6] Damghani A M, 2008. Municipal solid waste management in Tehran: current practices, opportunities and challenges. Waste Management. 28: 929-934.
[7] El-Salam, M. M. A. (2013).Journal of Environmental and Occupational Science. Journal of Environmental and Occupational Science, 2(3), 131-140.

[8] Farrell.M and Jones.DL, 2009.Critical evaluation of municipal solid waste composting and potential compost markets.Bioresource Technology.100: 4301- 4310.

[9] Hubbe, M. A., Nazhad, M., \& Sánchez, C. (2010).Composting as a way to convert cellulosic biomass and organic waste into high-value soil amendments: A review.BioResources, 5(4), 2808-2854.

[10] Jha, A. K., Li, J., Nies, L., \& Zhang, L. (2013). Research advances in dry anaerobic digestion process of solid organic wastes. African Journal of Biotechnology, 10(64), 1424214253.

[11] Jilani S, 2007. Municipal solid waste composting and its assessment for reuse in plant production.Pakistan Journal of Botany. 39: 271-277.

[12] Jin J, 2006.Solid waste management in Macao: practices and challenges. Waste Management . 26: 1045-1051.

[13] Kinman1987. Sanitary landfill disposal of urban SW. In: Workshop on SWM. New Delhi. Jan 16-17.

[14] Kumar Kaushal, R., Varghese, G. K., \&Chabukdhara, M. (2012).Municipal Solid Waste Management in India-Current State and Future Challenges: A Review.International Journal of Engineering Science \& Technology, 4(4).

[15] Mari I, 2005. Use of sulfur to control pH in composts derived from olive processing by-products. Compost Sci.Util.13: 281-287.

[16] Mbuligwe S. and Kassenga G, 2005. Feasibility and strategies for anaerobic digestion of solid waste for energy production in Dar-es-Salaam city Tanzania. Resources Conservation \& Recycling. 42: 183-203.

[17] Metin, E, ErÖztÜrk, 2003. Solid waste management practices and review of recovery and recycling operations in Turkey. Waste Management 23, pp. 425-432.

[18] Miller FC, 1992.Composting as a Process Based on the Control of Ecologically Selective Factors. In: Meting, F.B., Jr.(Ed), Soil Microbial Ecology, Applications in Agricultural and Environmental Management. Marcel Dekker, Inc., New York, pp. 515-544.

[19] MoghadamMR and Mokhtarani B, 2009. Municipal solid waste management in Rasht city. Iran. Waste Management .29: 485-489.

[20] Mor S, 2006. Municipal solid waste characterization and its assessment for potential methane generation: a case study. Total Environment. 371 (1): 1-10.

[21] NareshKumar K, 2009. Characterization of Municipal Solid Waste (MSW) and a proposed management plan for Kharagpur,West Bengal, India. Resources, Conservation and Recycling. 53:166-174.

[22] Raje D V, 2001.An approach to assess level of satisfaction of the residents in relation to SWM system. Waste Management and Research. 19: 12-19.

[23] Sharholy.M, 2008.Municipal solid waste management in Indian cities-A review.Waste Management. 28: 459-467. 
[24] Sharma VK, 1997. Processing of urban and agro-industrial residues by aerobic composting: Review.Energy convers. 38: 453-478.

[25] Siddiqui T, 2006.Sustainable development through integrated municipal solid waste management (MSWM) approach - a case study of Aligarh District. Paper presented at the National Conference of Advanced in Mechanical Engineering. New Delhi. India. AIME

[26] Vesilind P. A.,WorrellW. A., Reinhart DR, 2003.Solid waste engineering. Singapore: Thomson Asia Pvt. Ltd.,
[27] Ziaee, S., Omrani, G., Agha, M. M. A., \&Mansouri, N. (2012).Qualitative and Quantitative Examination of Household Hazardous Waste in Tehran. Advances in Environmental Biology, 6(2), 676-683.

[28] ZucconiF, 1987. Compost Specification for the Production and Characterization of Compost from Municipal Solid Waste, In: Compost Production, Quality and the use.(Eds): M.de. Bestoldi, M.P.Ferranti, P.L., Hermite and F. Zucconi. Elsevier Applied Science Publishing Co., Inc., New York, 